\title{
Morphological, anatomical, palynological, and micromorphological study on Diplotaxis tenuifolia (Brassicaceae)
}

\author{
Barış YILDIRIM ${ }^{1}$, Hüseyin DURAL ${ }^{1}$, Burcu YILMAZ ÇITAK ${ }^{* 1}$ \\ ORCID: 0000-0000-0000-0000; 0000-0000-0000-0000; 0000-0000-0000-0000 \\ ${ }^{1}$ Selçuk Üniversitesi, Fen Fakültesi, Biyoloji Bölümü, 42130, Konya, Türkiye
}

\begin{abstract}
The present study deals with the morphological, anatomical, and palynological properties of Diplotaxis tenuifolia. The stem cross-sections had a single-layered epidermis, parenchymatous cortex, vascular bundles, and parenchymatic pith cells. An equifacial mesophyll type was observed in the leaves with multiple-layered palisade tissue, but the spongy parenchyma was reduced. Vascular bundles were small except for the midrib. The cross-sections of the fruit had a single exocarp, 3- or 4-layered mesocarp, and single-layered endocarp. Transverse sections of the seed showed the presence of layers of epidermis, parenchyma, and endosperm.
\end{abstract}

Key words: anatomy, Brassicaceae, Diplotaxis, palynology, micromorphology

\section{Diplotaxis tenuifolia (Brassicaceae) üzerine morfolojik, anatomik, palinolojik ve mikromorfolojik bir araştırma}

\section{Özet}

Bu çalışmada Diplotaxis tenuifolia türünün morfolojik, anatomik, palinolojik ve mikromorfolojik özellikleri ele alınmaktadır. Gövde enine kesitleri, tek tabakalı epidermis, parankimatik korteks, iletim demetleri ve öz hücrelerini içermektedir. Yapraklarda, çok tabakalı palizat parankimalı ekvifasiyal tip mezofil gözlemlenmiş, fakat sünger parankiması indirgenmiştir. İletim demetleri orta damar hariç küçüktür. Meyve enine kesitleri tek bir ekzokarp, 3 ya da 4 tabakalı mezokarp ve tek tabakalı endokarpa sahiptir. Tohum enine kesitleri, epidermis, parankima ve endosperm tabakalarının varlığını göstermiştir.

Anahtar kelimeler: anatomi, Brassicaceae, Diplotaxis, palinoloji, mikromorfoloji

\section{Introduction}

Brassicaceae comprises c, 338 genera and c, 3700 species [1], including Arabidopsis thaliana (L.) Heynh., which has been used as the flowering plant model system [2]. In Turkey, Brassicaceae is represented by c, 571 species, with 65 subspecies, 24 varieties, and c, 660 taxa belonging to 91 genera [3, 4]. When the list of Turkish plants was published, this number was updated by 91 genera and 686 species [5]. The genus, Diplotaxis DC. (Brassicaceae, tribe Brassiceae), currently comprises 32 species or 34 [1], plus several additional infraspecific taxa, native to Europe, the Mediterranean Basin, SW Asia (up to the Himalayas), and Macaronesia. The genus Diplotaxis is represented by five taxa in Turkey $[6,7]$.

Turkish Diplotaxis species have been the subject of different research areas, such as allergy, germination, and agricultural studies [8,9]. The vegetative and generative organs and anatomical traits of the genus Diplotaxis are not well known [10]. In this study, D. tenuifolia was evaluated using its anatomical characteristics, vegetative organs, fruit, and seeds, and palynomorphological characteristics.

\footnotetext{
${ }^{*}$ Corresponding author / Haberleşmeden sorumlu yazar: Tel.: +903322232738; Fax.: +903322232738; E-mail: burcuyilmaz@ selcuk.edu.tr

(C) Copyright 2021 by Biological Diversity and Conservation $\quad$ Received: 17.03.2021; $\quad$ Published: 15.12.2021 BioDiCon. 963-0321
} 


\section{Materials and methods}

The plant materials were collected from the Campüs area of Selçuk University and surroundings in Konya Province. The collected materials (B.Çitak-283-H.Dural) were identified according to the classification of Hedge (1965) and the observations herein. Some of the plant materials were transferred to $70 \%$ ethyl alcohol during the field excursion. All of the plant specimens were stored in the KNYA herbarium and the Plant Anatomy Laboratory in the Biology Department.

\subsection{Methods}

\subsubsection{Anatomical analysis}

Parts of the roots, stems, leaves, petals, fruit, and seeds were cut into small pieces and then the paraffin method was applied, in which they were dehydrated and embedded with paraffin [11]. Paraffin blocks were constructed and the sections were prepared and stained with safranin-fast green. At least, five sections were investigated which were taken from five individuals of species. The best sections were chosen and photographed using a Leica DM 1000 light microscope (Wetzlar, Germany).

\subsubsection{Palynological analysis}

The methods of both Wodehouse (1935) and Erdtman (1960) were used to investigate the pollen grains [12, 13]. An average of 50 pollen grains were examined and evaluated. The polar and equatorial axes, colpus length and width, apocolpium, exine and intine thickness, and muri width were measured. The pollen grains were directly placed on aluminum stabs and photographed using a Zeiss Jeol Evo LS 10 scanning electron microscope (SEM) (Carl Zeiss NTS GmbH, Oberkochen, Germany). The pollen terminology of Punt et al. (2007) was followed [14].

\subsubsection{Micromorphological analysis}

In the micromorphological investigations, the mature fruit and seeds were selected under a stereomicroscope and stored in paper bag. At least 30 samples of the fruit and seeds were measured with regards to several characteristics, such as the fruit length and width, and seed width and length. Then, the fruit and seeds were transferred to the aluminum stab, covered with gold, and micro photographed using a Zeiss Jeol Evo LS 10 SEM.

\section{Results}

\subsection{Macro-morphological Results}

Perennial, semi-shrubs and herbs up to $120 \mathrm{~cm}$, glabrous or with a few scattered hairs, with a more or less woody base or much branched. Lower leaves linear-oblong or spathulate, entire, coarsely lobed or pinnatifid, up to 10 $\mathrm{cm}$ long, petiolate. Upper leaves entire or with linear lobes. Petals lemon-yellow, 2 times longer than sepals, c. $1.5 \times 1$ $\mathrm{mm}$, broadly obovate. Fruiting pedicels $20-32 \mathrm{~mm}$, erect-spreading. Stamens $10-11 \mathrm{~mm}$, anthers $4 \mathrm{~mm}$. Fruit straight, 20-45 × 1.5-2 mm including a short beak 1-2.5 mm; stipe 1-2 mm; stigma capitate, broader than beak. Seeds smooth, pale brown, numerous. Fl. 3-5. Roadsides and rocky slopes, $100 \mathrm{~m}$ a.s.1 (Figure 1).

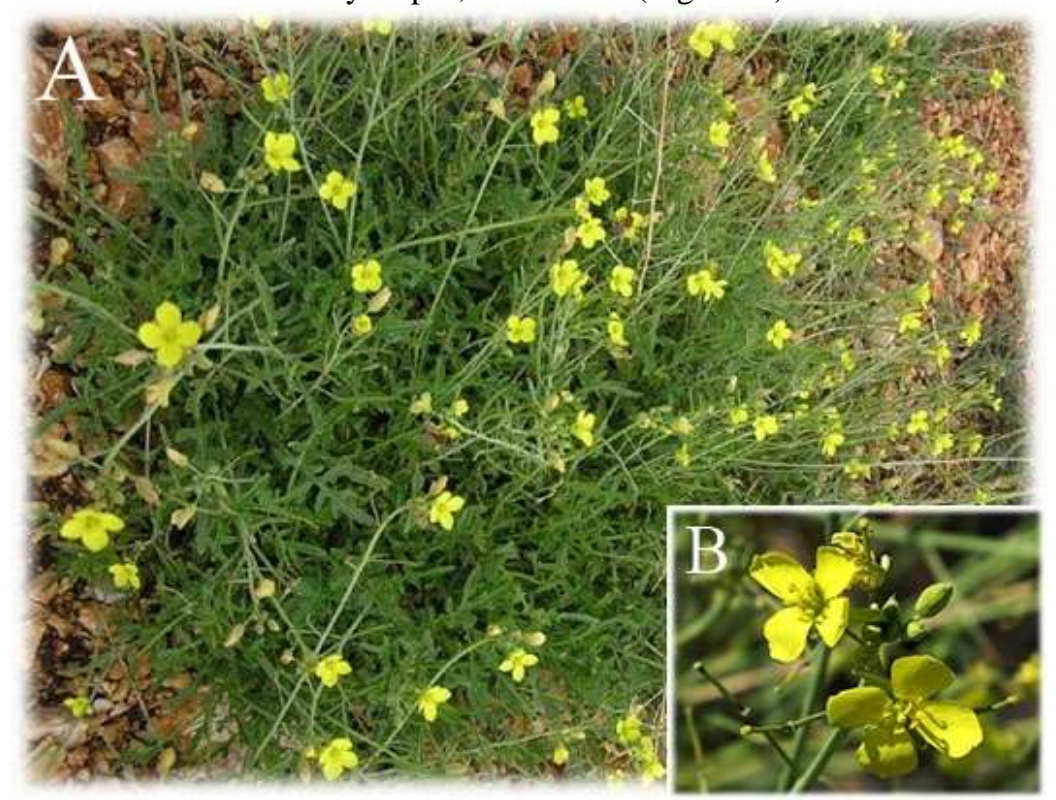

Figure 1. A. The general view of Diplotaxis tenuifolia in nature habitat. B. Flowers in close view 


\subsection{Micro-morphological Results}

\subsubsection{Fruit micromorphology}

The fruit were silique, $30-40 \times 1.5-2 \mathrm{~mm}$, slender, striate in ornamentation. Ovoid at base, carpels were not separated, narrowed and acute in the apex (Figs. 2-3).

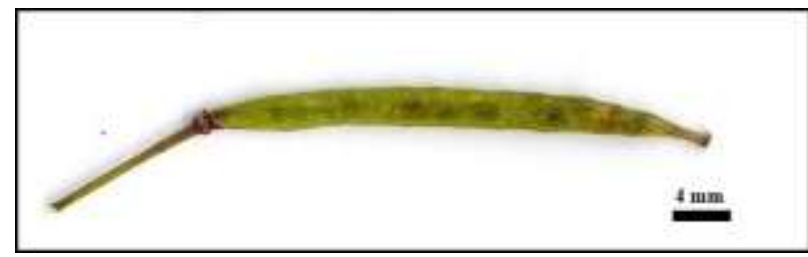

Figure 2. The general view of fruits of Diplotaxis tenuifolia (LM)
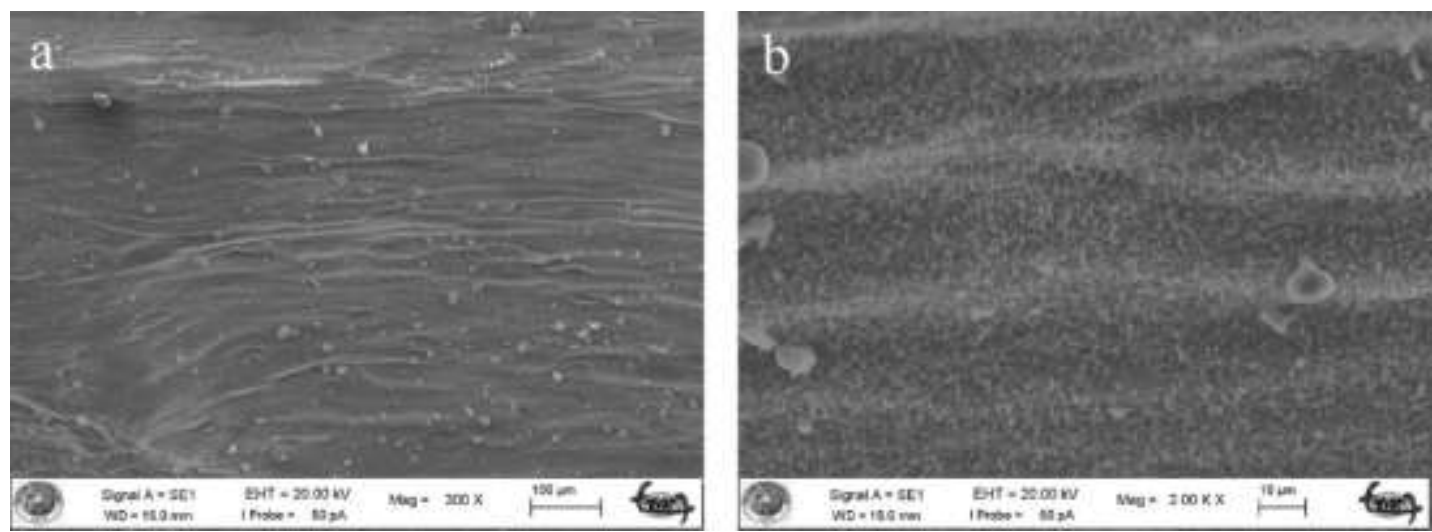

Figure 3. a-b. The ornamentation of fruits of Diplotaxis tenuifolia (SEM)

\subsubsection{Seed micromorphology}

The seeds of $D$. tenuifolia were subglobose, dark-brown and shiny, $1.21 \times 0.82 \mathrm{~mm}$, the ratio length-width was 1.47 , seed outline was oblong, chalazal pole was roundate, micropylar pole was acute, seed surface type was reticulate, concave, shape of epidermis was tetragonal, seed surface striate, suture was flat, 23.47-39.47 × 15.56-26.97 $\mu \mathrm{m}$ (Figure 4).
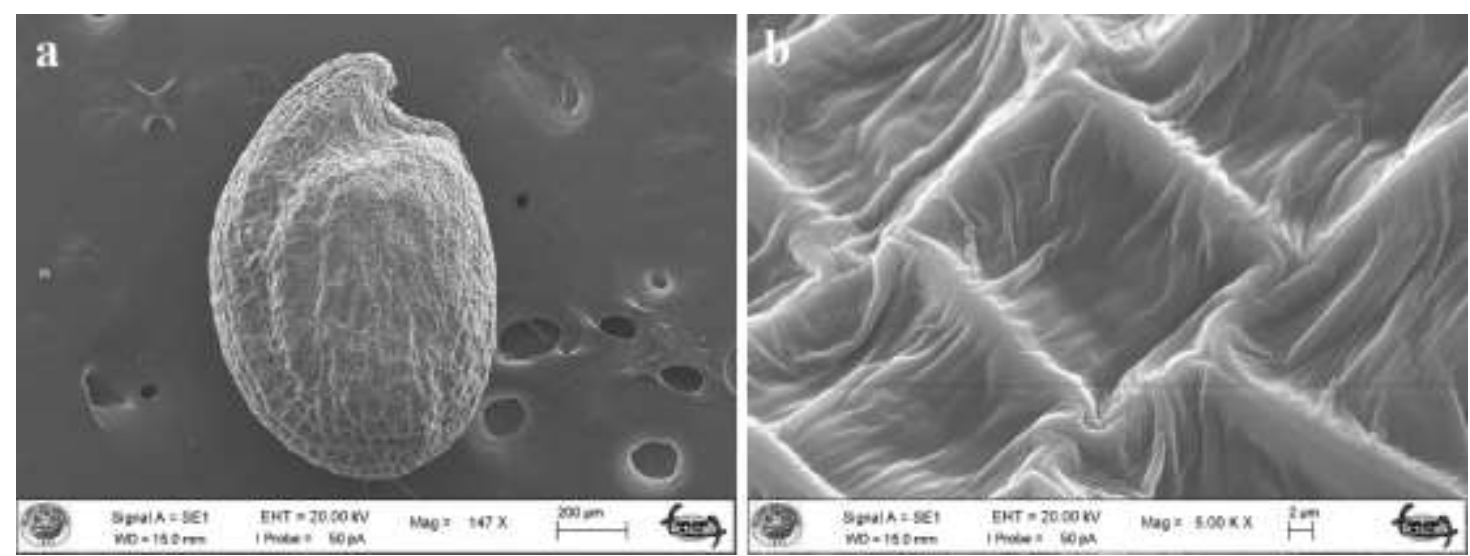

Figure 4. a. General view of the seeds of $D$. tenuifolia (SEM) b. Ornamentation

\subsection{Anatomical Results}

\subsubsection{Root anatomy}

The peridermis, which was characterized as many layered, partly broken, with phellem cells, was the outermost layer of the roots in D. tenuifolia (Figure 5-a). Cortex cells were parenchymatic, their shape was defined as rectangularoval, and they contained starch grains (Figure 5-b). The vascular tissue, composed of phloem and xylem elements, was well-developed. Trachea cells were measured with a mean value of $47.16 \mu \mathrm{m}$. The center of the roots contained only sclerenchyma cells (Figure 5-b). 


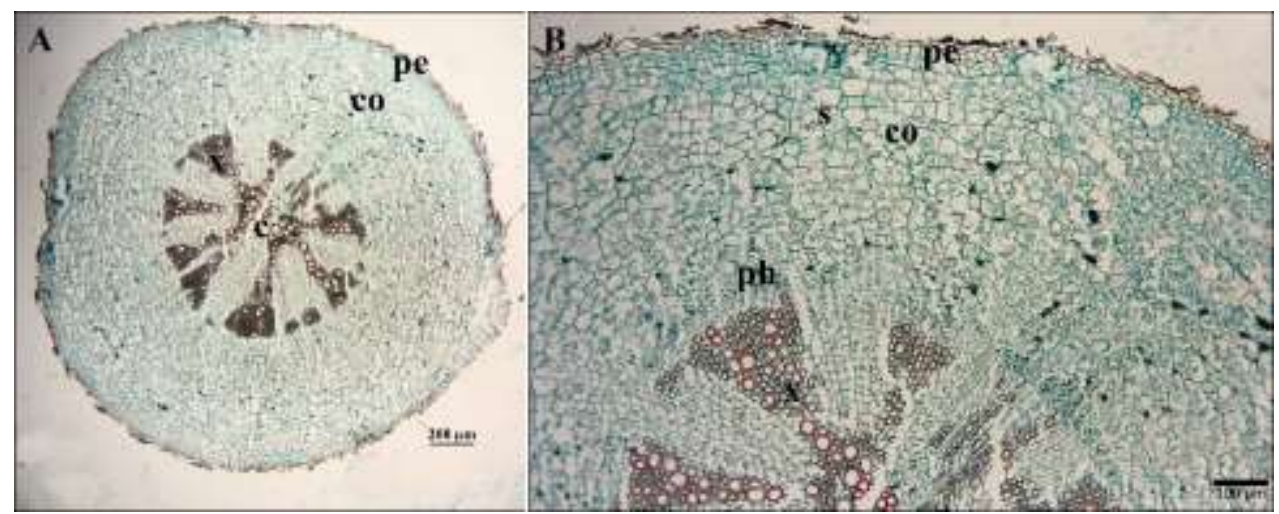

Figure 5. The root cross sections of $D$. tenuifolia. A. General view of roots pe: peridermis, co: cortex, x: xylem, c: center of root. B. the close view of roots s: starch grains, ph: phloem.

\subsubsection{Herbaceous stem anatomy}

The single epidermis layer of the outermost surface of the stem was limited (Figure 6-a,b). The cortex, which was characterized by parenchymatous cells, was oval-shaped with chloroplasts. Sclerenchyma was covered in a small area in the stem. Phloem and xylem were well-developed. The pith was composed of oval-shaped parenchymatic cells (Figure 6-a).

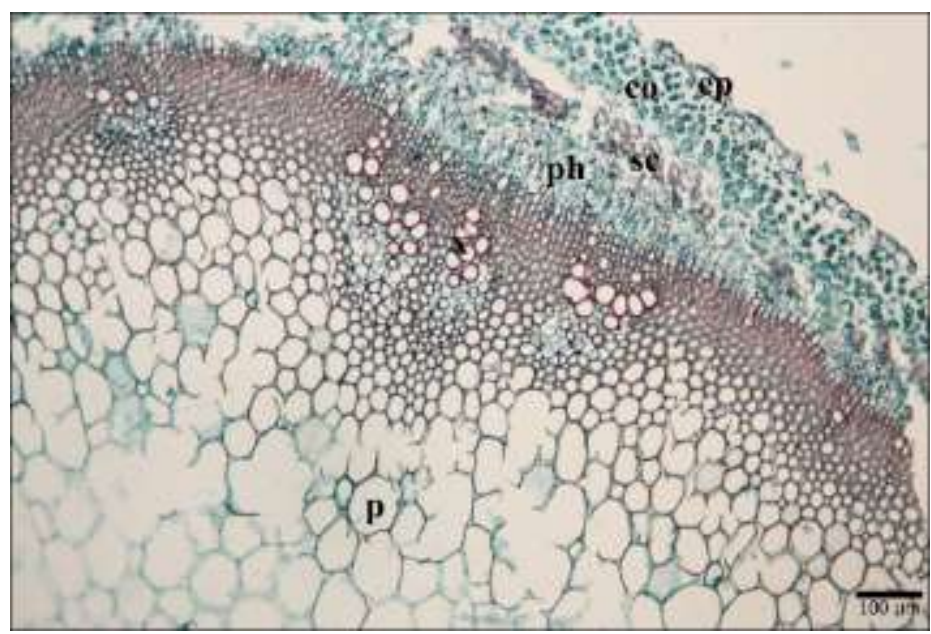

Figure 6. The cross section of herbaceous stem of $D$. tenuifolia. ep: epidermis, co: cortex parenchyma, sc: sclerenchyma, ph: phloem, x: xylem, p: parenchyma cell.

\subsubsection{Leaf anatomy}

The cross-sections of the leaves were clearly composed of 3 main anatomical parts, comprising the epidermis, mesophyll, and vascular tissue (Figure 7). A single-layer epidermis covered the leaf on both surfaces. Stomata occurred on both the upper and lower epidermis. Mesophyll tissue was composed of 2 types of cells, comprising palisade and sponge parenchyma. Central vascular bundle was larger and collateral in type (Figure 7).

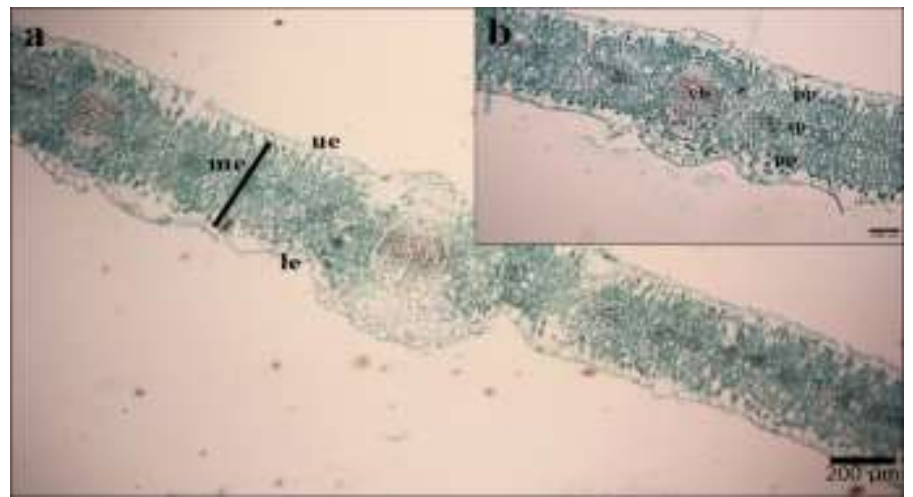

Figure 7. The cross sections of leaves of D. tenuifolia. a. General view and midrib of leaf ue: upper epidermis, le: lower epidermis, me: mesophyll. b. Close view of lamina pp: palisade parenchyma, sp: spongy parenchyma, vb: vascular bundle 


\subsubsection{Fruit and seed anatomy}

The transverse sections of the fruit were oval-shaped and the pericarp was composed of a lined exocarp, 3 or 4 rows of mesocarp, and a single-layered endocarp. There are septum and replum in cross sections (Figure 8a). The vascular bundle was located in the endocarp layer.

The cross-sections of the seed were used to examine the integuments, endosperm, and embryo. The seed crosssections showed that there was a single-layered epidermis. Single-layered parenchyma was under the epidermis. The endosperm layer was composed of rectangular-oval-shaped cells.

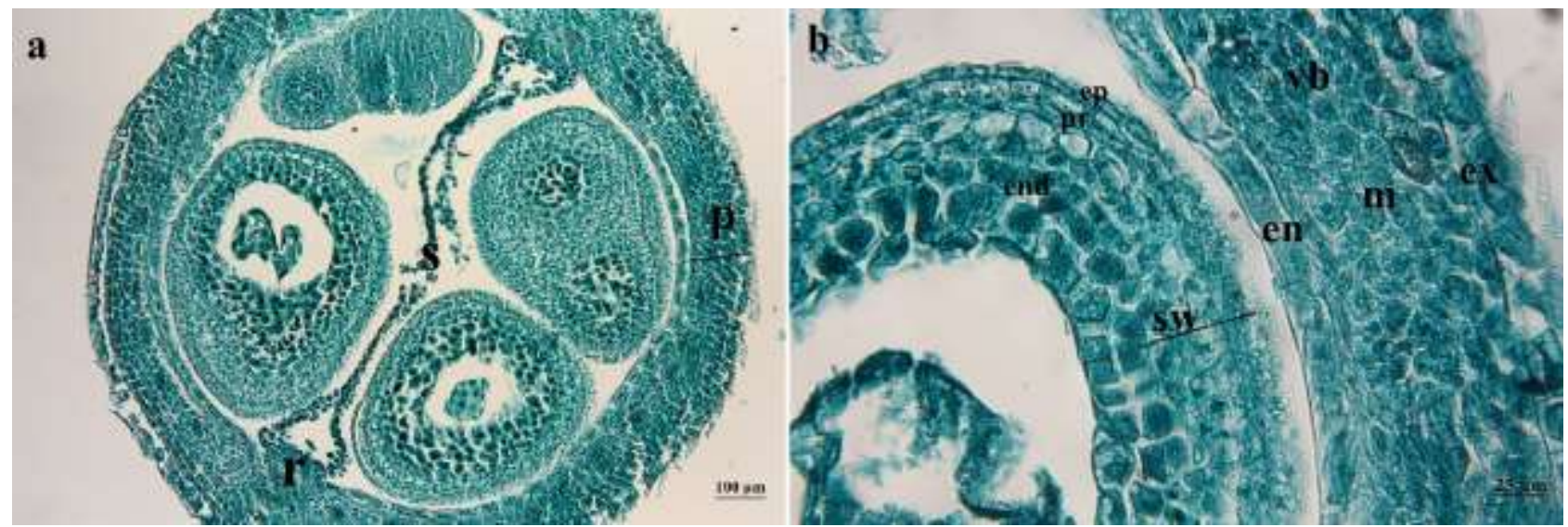

Figure 8. The cross sections of fruit and seed of D. tenuifolia. a. General view of fruit cross section p: pericarp, s: septum, r: replum b. Close view of pericarp and seed ex: exocarp, en: endocarp, m: mesocarp, vb: vascular bundle, sw: seed wall, ep: epidermis, pr: parenchyma, end: endosperm.

\subsection{Palynomorphological Results}

The pollen grains of $D$. tenuifolia were monad, tricolpate, and isopolar. The polar axis was measured as 22.69$24.44 \mu \mathrm{m}$ (mean: $23.77 \mu \mathrm{m}$ ), the equatorial axis was measured as $24.37-26.33 \mu \mathrm{m}$ (mean: $25.21 \mu \mathrm{m})$. The $\mathrm{P} / \mathrm{E}$ ratio was 0.94. Pollen shape was determined as oblate-spheroidal. The length of the colpus was measured as $17.7 \mu \mathrm{m}$, while the width of the colpus was measured as $20.07 \mu \mathrm{m}$. The exine was semitectate and the sculpture of the exine was determined as reticulate with smooth-walled, isodiametric-shaped muri. The exine was measured as $2.96-4.16 \mu \mathrm{m}$ (mean $3.37 \mu \mathrm{m}$ ), intine was $0.6-0.7 \mu \mathrm{m}$ (mean $0.64 \mu \mathrm{m})$.
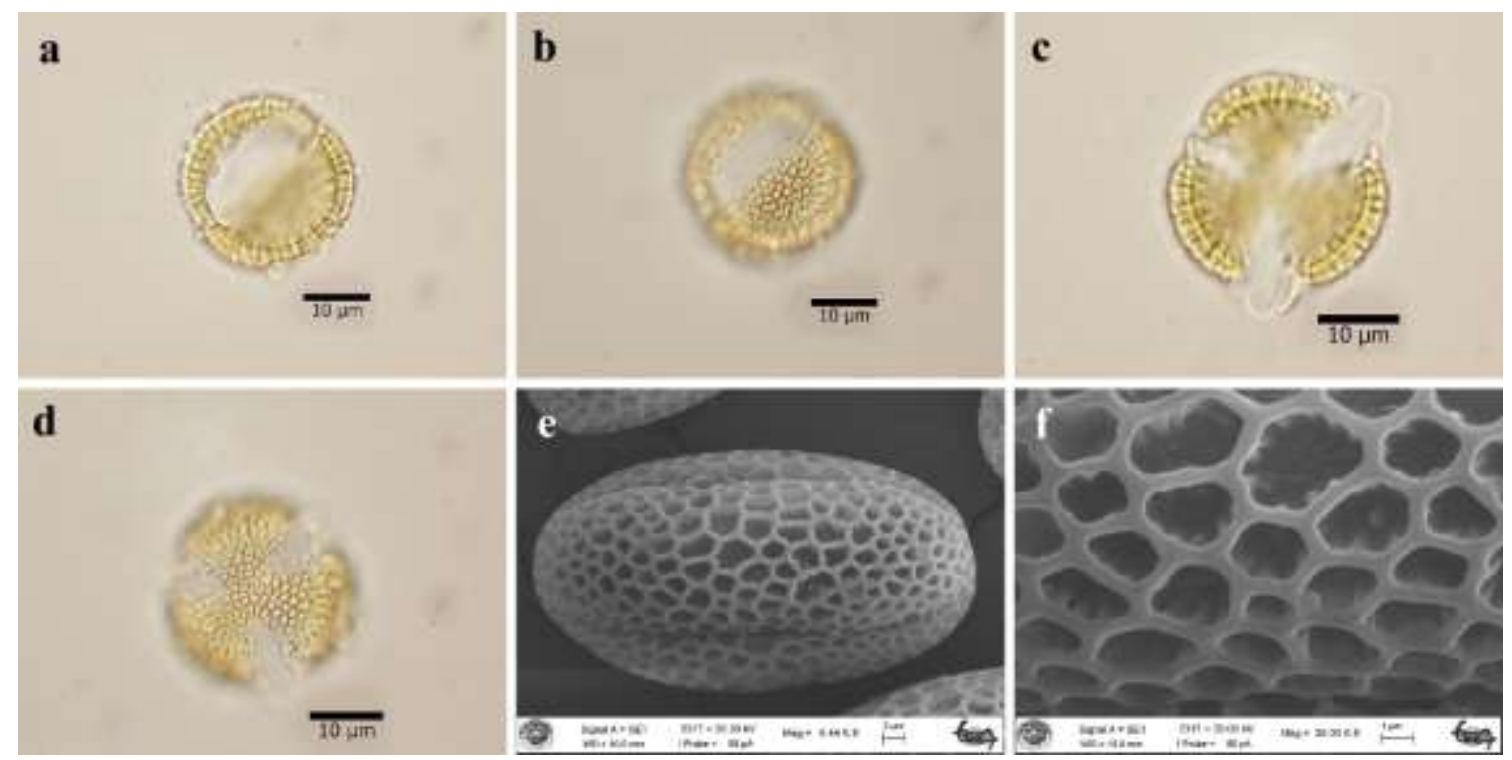

Figure 9. The light microscope (LM) and scanning electron microscope photographs of D. tenuifolia. a-d. The general view of pollen e-f. The sculpturing

\section{Conclusions and discussion}

The present study was the first report about the anatomical traits of the vegetative organs, fruit, and seeds of $D$. tenuifolia in the family Brassicaceae. The morphological measurements and observations of D. tenuifolia were 
congruent with those of the study of Hedge 1965. However, the dimensions and properties of the bracts, ovary, style, stigma, and stamen were presented for the first time herein, as different from those of previous studies.

In the root cross-section, the root center of D. tenuifolia was filled with xylem elements. Çitak and Dural (2020) reported that some species of the genus Iberis had parenchymatous cells in the root center [15]. The contour of the stem cross-sections was rounded with collenchymatic ridges that were ovoid or polygonal in the family Brassicaceae [15-18], while they were rectangular- and irregular-shaped in Diplotaxis harra [10]. The rounded-shaped cross-section of the stem in D. tenuifolia was observed with the general characteristics of the primary stem.

In Brassicaceae, unifacial, equifacial, and bifacial mesophyll have been reported by some researchers $[15,16,18]$. In the genus Diplotaxis, equifacial mesophyll was reported [10]. Accordingly, in the current study, $D$. tenuifolia also had equifacial mesophyll in its leaf anatomy, as was also reported in the study of Qader (2018)[10].

For the classification and identification of species in the family Brassicaceae, pollen and seed morphological characteristics can be used. Çitak et al. (2016) reported the measurements and descriptions of the pollen grains of $D$. tenuifolia using only a light microscope [19]. They additionally conducted scanning electron microscopy investigations to gain knowledge of the pollen morphology of $D$. tenuifolia, through which better identification was obtained. $D$. tenuifolia exhibited the general pollen characteristics of the family Brassicaceae. The pollen grains of the studied species were determined as tricolpate, oblate-spheroidal, and reticulate.

The fruit are always siliqua, with considerable variation regarding the position, length, and width, and proportional size of the parts in the genus Diplotaxis. The anatomy of the fruit and seeds provides important data about the taxonomy of the family Brassicaceae. In species of Brassicaceae, a living endosperm layer around the embryo plays an essential role in the regulation of the germination and dormancy of the seeds. A single-layered endosperm surrounded the embryo of D. tenuifolia, as Lenser et al. (2016) reported in A. arabicum, and Dural and Ç1tak (2020) reported in Ae. dumanii [20, 21]. In the genus Aethionema, 1- or 2-layered epidermis of the testa were reported by some researchers [21, 22]. Anatomical, micromorphological, and palynological characteristics might be useful in the definition of $D$. tenuifolia. Nevertheless, these characteristics will be more valuable if other species of Diplotaxis are also investigated. In conclusion, D. tenuifolia was researched in the current work and the anatomical characteristics of the stem, leaves, fruit, and seeds, and fruit and seed micromorphology were determined for the first time herein.

\section{Acknowledgements}

The authors are thankful to the Research Foundation of Selçuk University for their financial support (Project number: 18201044).

\section{References}

[1] Warwick, S., Francis, A. \& Al-Shehbaz, I. (2006). Brassicaceae: species checklist and database on CD-Rom. Plant Systematics and Evolution 259 (2-4), 249-258.

[2] Mühlhausen, A., Lenser, T., Mummenhoff, K. \& Theißen, G. (2013). Evidence that an evolutionary transition from dehiscent to indehiscent fruits in Lepidium (Brassicaceae) was caused by a change in the control of valve margin identity genes. The Plant Journal 73, 824-835. https://doi.org/10.1111/tpj.12079

[3] Al-Shehbaz, I.A., Beilstein, M.A. \& Kellogg, E.A. (2006). Systematics and phylogeny of the Brassicaceae (Cruciferae): an overview. Plant Systematics and Evolution 259, 89-120. https://doi.org/10.1007/s00606-006$\underline{0415-z}$

[4] Al-Shehbaz, I.A., Mutlu, B. \& Dönmez, A.A. (2007). The Brassicaceae (Cruciferae) of Turkey, Updated. Turkish Journal of Botany 31, 327-336.

[5] Güner, A., Aslan, S., Ekim, T., Vural, M. \& Babaç, M.T. (2012). Türkiye Bitkileri Listesi (Damarlı Bitkiler). Nezahat Gokyiğit Botanik Bahcesi ve Flora Araştırmaları Derneği Yayını, İstanbul.

[6] Hedge, I.C. (1965). Diplotaxis. Flora of Turkey And The East Aegean Islands, vol. I. Edinburgh Univ. Press.

[7] Erik, S. (2012). Çok Yönlü Ruderal Bir Tür: Diplotaxis tenuifolia (L) DC. Ankara Üniversitesi Çevrebilimleri Dergisi 4 (1), 27-35.

[8] Troiano S, Novelli, V, Geatti P, Marangon F, Ceccon L. (2019). Assessment of the sustainability of wild rocket (Diplotaxis tenuifolia) production: Application of a multi-criteria method to different farming systems in the province of Udine, Ecological Indicators, 97: 301-310.

[9] Guijarro-Real, C., Prohens, J., Rodríguez-Burruezo, A., \& Fita, A. (2019). Potential of wall rocket (Diplotaxis erucoides) as a new crop: Influence of the growing conditions on the visual quality of the final product. Scientia Horticulturae 258, 108778. https://doi.org/10.1016/j.scienta.2019.108778

[10] Qader, K.O. (2018). Taxonomic Significance of Anatomical Characters in Some Species of Brassicaceae family. University of Thi-Qar Journal of Science 6(4), 77-83.

[11] Johansen, D. A. (1940). Plant microtechnique, McGraw-Hill Book Company, Inc: London; 530p.

[12] Wodehouse, R.P. (1935). Pollen grains: their structure, identification and signifiance in science and medicine. McGraw Hill, New York \& London, 574 pp. 
[13] Erdtman, G. (1960). The acetolysis method-a revised description. Svensk Botanisk Tidskrift 54, 516-564.

[14] Punt, W., Hoen, P.P., Blackmore, S., Nilsson, S. \& Le Thomas, A. (2007). Glossary of pollen and spore terminology. Review of Palaeobotany and Palynology 143, 1-81. https://doi.org/10.1016/j.revpalbo.2006.06.008

[15] Çıtak, B.Y. \& Dural, H. (2020). The anatomical structures of the genus Iberis L. (Brassicaceae) in Turkey. Bangladesh Journal of Plant Taxonomy 27(2), 213-224. https://doi.org/10.3329/bjpt.v27i2.50662

[16] Atçeken, M.M., Dural, H. \& Çıtak, B.Y. (2016). The morphological, anatomical and palynological investigations on some taxa of Genus Aethionema at Waiton (Brassicaceae). Biological Diversity and Conservation 9, 55-68.

[17] Gönen, B., Dural, H. \& Çıtak, BY. (2019). A Survey of the morphology, anatomy, and palynology of endemic Bornmuellera kiyakii and B. glabrescens (Brassicaceae) from Turkey. Gazi University of Journal of Science 32, 776-790. https://doi.org/10.35378/gujs.455316

[18] Akbar, F. \& Begum, K. (2020). A comparative anatomical investigation of three taxa of Brassica L. from Bangladesh. Bangladesh Journal of Plant Taxonomy 27(1), 15-26. https://doi.org/10.3329/bjpt.v27i1.47566

[19] Çıtak, B.Y., Dural, H. \& Gönen, B. (2016). Selçuk Üniversitesi Alâeddin Keykubat Kampüsü’nde Yayılış Gösteren Bazı Bitkilerin Polen Morfolojileri. Selçuk Üniversitesi Fen Fakültesi Fen Dergisi 42(1), 42-56.

[20] Lenser, T., Graeber, K., Çevik, Ö.S., Adıgüzel, N., Dönmez, A.A., Grosche, C., Kettermann, M., MaylandQuellhorst, S., Mérai, Z., Mohammadin, S., Nguyen, T., Rümpler, F., Schulze, C., Sperber, K., Steinbrecher, T., Wiegand, N., Strnad, M., Scheid, O.M., Rensing, S.A., Schranz, M.E., Theißen, G., Mummenhoff, K., LeubnerMetzger, G. 2016. Developmental control and plasticity of fruit and seed dimorphism in Aethionema arabicum. Plant Physiology 172, 1697-1707.

[21] Dural, H. \& Çıtak, B.Y. (2020). The Anatomical Characteristics of Endemic Aethionema dumanii Vural \& Adıgüzel (Brassicaceae). Kahramanmaraş Sütçü İmam Üniversitesi Tarım ve Doğa Dergisi 23 (2), 435-440

[22] Karaismailoğlu, C. (2019). Comparative morphology and anatomy of seeds of some Aethionema W.T. Aiton (Brassicaceae) taxa from Turkey. Bangladesh Journal of Plant Taxonomy 26, 1-12. https://doi.org/10.3329/bjpt.v26i1.41911 